DOI: https://doi.org/10.24127/ajpm.v10i4.4005

\title{
REFLEKSI PEMBELAJARAN BERBASIS DIDACTICAL DESIGN RESEARCH SEBAGAI UPAYA PENGEMBANGAN PROFESIONAL GURU PAUD
}

\author{
Vici Suciawati ${ }^{1}$, Mohamad Gilar Jatisunda ${ }^{2 *}$, Dede Salim Nahdi ${ }^{3}$ \\ 1,2* Pendidikan Matematika, Universitas Majalengka, Kota Majalengka, Indonesia \\ ${ }^{3}$ Pendidikan Guru Sekolah Dasar, Universitas Majalengka, Kota Majalengka, Indonesia \\ *Corresponding author. \\ E-mail: $\frac{\text { vicisuciawati@unma.ac.id }}{\text { g.jatisunda@unma.ac.id }}{ }^{\left.{ }^{*}\right)}$
}

Received 16 July 2021; Received in revised form 13 September 2021; Accepted 20 December 2021

\begin{abstract}
Abstrak
Kompetensi professional guru pendidikan anak usia dini menjadi salah satu faktor penting untuk memprediksi dan meningkatkan kualitas pembelajaran, melalui pengembangan professional guru Pendidikan anak usia dini diharapkan pengetahuannya tetap terjaga dan bahkan meningkat, sebagai modal mengajarkannya kembali. Tujuan dari penelitian ini untuk mendeskripsikan proses refleksi pembelajaran berbasis didactical design research sebagai upaya pengembangan profesional. Metode penelitian menggunakan kualitatif dengan desain fenomenologi. Partisipan dipilih secara purposive sampling pada penelitian ini adalah satu orang guru pendidikan anak usia dini. Pengumpulan data menggabungkan data dari observasi, wawancara dan focus group discussion. Teknik analisis data yang digunakan adalah Interpretative Phenomenological Analysis (IPA). Hasil penelitian menunjukan bahwa learning obstacles yang di hadapi oleh siswa berdasarkan hasil analisis guru mengarah pada epistemological obstacle. Guru memaknai konsep segitiga sebagai bentuk bangun datar yang memiliki tiga sisi dan persegi merupakan bangun datar yang memiliki empat sisi. Guru membuat hypothetical learning Trajectory berdasarkan hasil analisis yaitu learning obstacles dan concept image.
\end{abstract}

Kata kunci: Didactical design research; guru pendidikan anak usia dini; pengembangan professional.

\begin{abstract}
The competence of early childhood education teachers is one of the essential factors to predict and improve the quality of learning. Through the development of early childhood professional teachers, it is hoped that their knowledge will be maintained and even increased to re-teach them. The purpose of this study is to describe the process of reflection on didactic design-based learning as a professional development effort. The research method uses a qualitative phenomenological design. The participant selected by purposive sampling in this study was one early childhood, education teacher. Data collection combines data from observations, interviews, and focus group discussions. The data analysis technique used is Interpretative Phenomenological Analysis (IPA). The results showed that the learning barriers faced by students based on the results of the teacher's analysis led to epistemological barriers. The teacher interprets the concept of a triangle as a flat shape with three sides, and a square is a flat shape with four sides. The teacher hypothesizes a learning trajectory based on the analysis results, namely learning obstacles and concept images.
\end{abstract}

Keywords: Didactical design research; early childhood education teachers; professional development.

This is an open access article under the Creative Commons Attribution 4.0 International License

\section{PENDAHULUAN}

Proses pembelajaran di PAUD bertujuan mengajarkan konsep dasar yang bermakna berbasis pengalaman nyata untuk membantu pertumbuhan dan perkembangan supaya siap mengikuti Pendidikan selanjutnya (Apriyanti, 2017; Lisa, 2017). 
Matematika merupakan bahasa yang digunakan untuk mengkomunikasikan gagasan yang bersifat spasial seperti garis bilangan, numerik, dan aritmatika yang berbasis geometris (Jung \& Conderman, 2017). Geometri merupakan cabang Matematika yang berfungsi untuk pengembangan berpikir kritis dan pemecahan masalah (Bintoro \& Sumaji, 2021). Konsep-konsep geometris juga mendasari semua pemikiran matematika (Khali \& Khalil, 2019). Sehingga konsep geometri harus diberikan pada Pendidikan anak usia dini sebagai pondasi berpikir logis siswa.

Ketika mengajarkan geometri sesungguhnya guru PAUD meletakan pondasi pengembangan berpikir matematika yang lebih kompleks ditingkat selanjutnya. Sedini mungkin pembelajaran geometri pada siswa PAUD diperkenalkan bahwa concept image sejalan dengan concept definition (Tsamir et al., 2015). Simbol, teorema, representasi, properti-properti, atau aspek-aspek lainnya terkait dengan konsep merupakan bagian dari struktur kognitif (Verissimo et al., 2017). Pengelolaan yang baik diantara bagianbagian struktur kognitif tersebut sangat penting untuk pengembangan pemikiran matematis yang kuat (de Weerd \& Verhoef, 2015).

Concept image merupakan cakupan semua struktur mental yang berkaitan dengan sebuah konsep matematika yang dibangun melalui pengalaman (Dreyfus, 2014) dan concept definition adalah definisi formal yang spesifik menjelaskan semua atribut konsep matematika (Beynon \& Zollman, 2015; Johnson et al., 2014). Concept image mungkin tidak mencerminkan secara utuh concept definition, concept image terus berkembang saat siswa menemukan ide matematika baru (Engelke Infante et al., 2018; Habineza, 2013). Proses pemaknaan konsep matematika bersifat subyektif (concept image) kemudian mengarah pada konteks institusionalisasi (concept definition) ataupun sebaliknya (Suryadi, 2015). Berdasarkan hasil penelitian setiap jenjang usia tidak cukup hanya mengetahui deskripsi verbal yang benar suatu konsep, artinya memiliki concept image terbatas akan mengalami kesulitan mempelajari dan menerapkan deskripsi tersebut (Clements \& Sarama, 2011).

Kemudian Guru berperan penting menentukan tercapainya tujuan pembelajaran dan kemajuan akademis siswa (Barut et al., 2020). Efek kumulatif dari cara mengajar efektif guru berdampak pada cara berpikir siswa (Lo, 2021). Sehingga ketika mengajarkan geometri tidak efektif, dikhawatirkan concept image yang terbentuk pada pemikiran siswa tidak sesuai dengan konsep sebenarnya yang menyebabkan kesalahan memahami konsep. Beberapa faktor yang menyebabkan hal tersebut diantaranya karena kemampuan guru dalam memahami konsep geometri. Hasil penelitian menunjukkan bahwa pengetahuan konten matematika guru pada materi geometri sangat kurang untuk guru pada tingkat dasar $(\mathrm{Ng}$, 2011). Kualitas pemahaman materi guru terhadap konsep matematika memberikan kontribusi terhadap pemahaman dan kemampuan berpikir matematis yang baik (Rudi et al., 2020).

Faktanya sedikit literatur menunjukkan bahwa guru Pendidikan anak usia dini mengajar geometri dengan efektif (Clements \& Sarama, 2011). Hal tersebut tercermin pada ilustrasi guru yang tidak mencerminkan konsep, keterampilan, dan perspektif 
yang luas terkait yang penting dalam domain berpikir geometri dan spasial (Clements \& Sarama, 2011). Fakta lainnya guru sering mengabaikan konsepsi awal siswa tentang materi yang sedang dipelajarinya (Maizora \& Rosjanuardi, 2020). Disamping itu siswa pendidikan anak usia dini dianggap tidak mampu secara kognitif terlibat dalam proses berpikir yang diperlukan untuk memahami matematika (Hachey, 2013).

Berdasarkan uraian diatas terdapat dua faktor yang menentukan keberhasilan proses pembelajaran yaitu faktor siswa dan tentunya faktor guru sebagai orang yang paling bertanggung jawab terlaksananya proses pembelajaran. Faktor guru menjadi isu yang sangat menarik untuk di kaji berdasarkan Peraturan Menteri Pendidikan Nasional (Permendiknas) nomor 16 tahun 2007 tentang standar kompetensi guru salah satu kompetensi yang harus dimiliki guru adalah melakukan tindakan reflektif untuk peningkatan kualitas pembelajaran.

Isu terkait dengan pengembangan professional guru sangat penting untuk di tindak lanjuti. Selama ini pengembangan professional guru PAUD dilaksanakan berbasis lesson study dengan hasil dapat meningkatkan kompetensi profesional guru PAUD, yang ditandai dengan adanya peningkatan pada pengembangan, pemilihan dan pengolahan materi pembelajaran yang diajar secara kreatif (Fauzi, 2017; Susianna \& Suhandi, 2014). Kemudian pengembangan profesioanal lainnya adalah pengembangan profesional berkelanjutan (Maiza \& Nurhafizah, 2019; Waspodo, 2012). Kedua proses pengembangan professional yang telah dilaksanakan kedua berorientasi pada refleksi pembelajaran dengan lebih berorientasi pada pencapaian tujuan, sehingga permasalahan terkait keragaman proses, hambatan, dan lintasan belajar siswa bisa jadi bukan merupakan substansi utama dari refleksi pembelajaran (Suryadi, 2013b).

Refleksi pembelajaran merupakan salah satu bentuk pengembangan profesionalisme guru (Liu \& Zhang, 2014). Sehingga perlu alternatif pengembangan professional guru pendidikan anak usia dini yang berorientasi pada proses refleksi pembelajaran. Didactical Design Research (DDR) menjadi alterntif, dimana DDR merupakan kerangka teori yang memadukan teori situasi didaktis dengan proses berpikir reflektif yang dilakukan guru sebelum, pada saat dan setelah pembelajaran (Suryadi, 2013b). DDR merupakan kerangka teori, konseptual, dan metodologis dalam pelaksanaan refleksi pembelajaran (Suryadi, 2018). Karena tujuan utama dari Pengembangan professional adalah meningkatnya kualitas pembelajaran dikelas (Harris \& Sass, 2011; Lasauskien et al., 2015). Tujuan utama dari penelitian ini adalah untuk mendeskripsikan proses refleksi pembelajaran sebagai pengembangan professional guru pendidikan anak usia dini berbasis didactical design research (DDR) pada pembelajaran geometri.

\section{METODE PENELITIAN}

Metode yang di gunakan dalam penelitian ini adalah kualititatif. Desain penelitian yang digunakan adalah fenomenologi. Studi tentang fenomenologi merupakan studi naratif yang mendeskripsikan pengalaman individu atau beberapa individu terhadap berbagai pengalaman hidup terkait dengan sebuah konsep atau fenomena (Creswell, 2012). Fenomenologi merupakan studi 
pengalaman dari perspektif individu (introspective human science) untuk menafsirkan dan memahami yang berkaitan dengan mengamati, mengukur, menjelaskan, dan memprediksi (van Manen, 2016). Fenomenologi hermeneutik lebih kompleks daripada fenomenologi deskriptif. Kompleksitas tambahan ini merupakan upaya Heidegger untuk memberikan lebih banyak kejelasan tentang fenomena bagi filsuf atau peneliti, fokusnya adalah memahami makna pengalaman dengan mencari tema, terlibat dengan data secara interpretatif, dengan sedikit penekanan pada esensi yang penting bagi fenomenologi deskriptif (Sloan \& Bowe, 2014).

Penenlitian ini dilaksanakan pada komunitas HIMPAUDI kecamatan Rajagaluh Kabupaten Majalengka. Partisipan pada penelitian ini adalah guru Pendidikan anak usia dini dengan jumlah satu orang. Observasi partisipan, wawancara, dan diskusi kelompok terarah (Creswell, 2012). Observasi partisipatif adalah suatu bentuk pengumpulan data yang melibatkan orang-orang yang berpartisipasi dan diamati selama suatu periode (Moser \& Korstjens, 2018). Teknik pengumpulan data penelitian yang dalam penelitian ini adalah menggabungkan Observasi, Wawancara, studi Dokumen. Observasi dilakukan untuk mengamati proses pelaksanaan refleksi pembelajaran berbasis didactical design research. Ketika partisipan telah selesai melaksanakan tahapan refleksi pembelajaran wawancara dilakukan. Pendekatan wawancara yang digunakan tidak terstruktur dan informal, memungkinkan untuk fleksibilitas yang lebih besar dalam menafsirkan pengalaman guru melakukan refleksi pembelajaran.
Interpretative Phenomenological Analysis (IPA) adalah teknik yang semakin populer untuk penelitian kualitatif yang bertujuan untuk memahami bagaimana orang merasakan dan memahami pengalaman mereka. Analisis kualitatif umumnya tidak digunakan untuk menemukan data dalam hal frekuensi tetapi digunakan untuk menganalisis makna data yang muncul di permukaan-interpretatif analisis fenomenologis seperti yang ditulis oleh (Smith et al., 2021). Tahapan analisis fenomenologi interpretatif adalah sebagai berikut: 1) membaca dan membaca ulang; pembacaan berulang juga memungkinkan analis untuk membangun model struktur wawancara secara keseluruhan dan memahami bagaimana narasi dapat menghubungkan bagian yang berbeda dari sebuah wawancara. 2) catatan awal; komentar deskriptif berfokus pada penggambaran isi dari apa yang dikatakan partisipan, subjek pembicaraan dalam transkrip (teks standar), komentar linguistik yang berfokus pada eksplorasi penggunaan bahasa tertentu oleh partisipan (miring). Validasi data melalui triangulasi sebagai teknik pemeriksaan keabsahan data dengan membandingkan hasil observasi, studi dokumen dan wawancara terhadap objek penelitian.

\section{HASIL DAN PEMBAHASAN}

Secara umum hasil analisis temuan data penelitian dan pembahasannya adalah analisis terkait dengan isu-isu yang menjadi point penting pada setiap pertemuan proses refleksi diataranya adalah learning obstacles, concept image dan hypothetical learning trajectory. 
DOI: https://doi.org/10.24127/ajpm.v10i4.4005

\section{a. Learning Obstacles}

Temuan berdasarkan dokumentasi dan wawancara pada pertemuan pertama penelitian 2204etika2204n besar guru menyadari bahwa Pendidikan anak usia dini menjadi tempat bagi anak untuk memulai belajar dan memperluas interaksi dengan lingkungan melalui kegiatan bermain. Strategi yang digunakan dalam pelaksanaan pembelajaran pengenalan geometri dengan bermain bagi anak usia dini. Aktivitas bermain merupakan sarana pembelajaran yang dapat memberikan makna dan pengetahuan baru. Isu yang menjadi kajian selanjutnya adalah terkait dengan perkembangan kognitif anak usia dini. Aktivitas bermatematika menjadi salah satu indicator anak mengalami perkembangan secara kognitif. Dalam lingkup ini, terdapat beberapa aspek diantaranya mengenai konsep bentuk, warna, dan ukuran. Aktivitas bermatematika anak usia dini lebih spesifik pada pengenalan geometri segitiga, persegi, dan lingkaran. Tujuan pembelajaran geometri pada anak usia dini adalah kemampuan anak mengenal, menunjuk, menyebutkan serta mengumpulkan benda-benda di sekitar berdasarkan bentuk geometri. Pada anak usia dini dimulai dengan membangun konsep yaitu mengidentifikasi ciri-ciri bentuk geometri.

Rancangan desain pembelajaran geometri para guru Pendidikan anak usia dini pada mengarah terhadap tujuan pembelajaran geometri di Pendidikan anak usia dini yaitu kemampuan mengetahui, mengenal, dan menerapkan. Terdapat tiga jenis learning obstacle yaitu ontogenic obstacle, didactical obstacle, dan epistemological obstacle (Brousseau, 1989). Ontogenic obstacle terjadi karena keterbatasan diri siswa yang berkaitan dengan kesiapan mentalnya untuk menerima pembelajaran. Didactical obstacle terjadi karena metode ataupun pendekatan yang digunakan ketika menyampaikan pembelajaran. Terakhir, epistemological obstacle terjadi karena keterbatasan pengetahuan yang dimiliki siswa pada konteks pengetahuan tertentu. Berdasarkan tes kemampuan geometri yang guru buat dan berdasarkan analisis yang di lakukan terdapat dua learning obstacles yang di hadapi oleh anak usia dini yang di sajikan pada Tabel 1 .

Tabel 1. Identifikasi learning obstacles

\begin{tabular}{lll}
\hline No & \multicolumn{1}{c}{ Temuan } & Kategori Leaning Obstcales \\
\hline 1 & Kesulitan mengingat dan mengenal bentuk geometri & Epistemological obstacles \\
2 & Kesulitan memahami bagian-bagian bentuk geometri & Epistemological obstacles \\
\hline
\end{tabular}

Fenomena yang menjadi objek kajian didactical design research yaitu dampak desain didaktis yang mengakibatkan learning obstacles pada siswa. Kajian terhadap learning obstacles yang di hadapi siswa yaitu "Kesulitan mengingat dan mengenal bentuk geometri" dan "Kesulitan memahami bagian-bagian bentuk geometri" . Adapun kategori learning obstacles yang di hadapi siswa adalah kategori epistemological obstacle yaitu terjadi karena kurangnya pengetahuan siswa terkait dengan konsep yang dipelajarinya. Epistemological obstacle merupakan hambatan yang muncul akibat dari pengetahuan seseorang yang terbatas pada konteks (Suryadi, 2010). Beberapa penelitian terkait dengan epistemological obstacles yang dihadapi 
DOI: https://doi.org/10.24127/ajpm.v10i4.4005

oleh siswa. Salah satunya siswa memahami konsep hanya 2205etika2205n atau parsial, sehingga 2205etika dihadapkan pada konteks yang berbeda siswa mengalami kesulitan dalam menggunakannya (Insani \& Kadarisma, 2020). Epistemological obstacles terjadi karena keterbatasan konteks pada siswa yang menyebabkan kesalahan dalam mengerjakan soal (Rohimah, 2017). Epistemological obstacles juga terjadi karena rendahnya kemampuan siswa dalam menafsirkan soal (Nuraeni et al., 2021). Kemudian terakhir epistimological obstacles muncul dari kesalahankesalah pengerjaan soal yang diakibatkan oleh keterbatasan konteks pengetahuan yang dimiliki siswa (Rohmah, 2019). Epistemological obstacles juga menyebabkan pengetahuan siswa hanya terbatas pada konteks tertentu, karena pemberian konteks dan soal oleh guru yang tidak variatif (Lestarai, 2019).

Berdasarkan penelitian terdahulu epistemological obstacles terjadi karena proses pembelajaran tidak memberikan fasilitas bagi siswa untuk memperoleh pengetahuan yang utuh terhadap suatu konsep geometri. Keterbatasan pengetahuan matematika dasar dan keterbatasan pengetahuan perkembangan matematika anak (Noviyanti, 2019). Pada penelitian ini juga terdapat terdapat indikasi rancangan proses pembelajaran yang digunakan membuat anak tidak mendapatkan secara utuh pengetahuan konsep geometri. Salah satu intervensi yang bisa dilakukan pertama kali adalah dengan memberikan scaffolding dan membiasakan siswa untuk mengungkapkan ide-ide matematisnya serta integrasi permasalahan dengan kehidupan seharihari (Rismayantini et al., 2021).
Berdasarkan temuan epistemological obstacle guru harus melakukan refleksi dengan lebih mendalam untuk meminimalkan dan bahkan mengatasinya tepat sesuai dengan kebutuhan siswa. Kemampuan melaksanakan refleksi pembelajaran merupakan bagian dari pengembangan profosional guru, agar pengetahuannya tetap terjaga. Karena setiap apa yang di sampaikan oleh guru pada pembelajaran merupakan gambaran sejauh mana guru memahami konteks yang di ajarkannya. Tentunya ini akan sangat berpengaruh terhadap pemahaman dan proses memaknai konsep siswa. Analisis learning obstacles khususnya epistemological obctacle sangat terkait erat dengan pengetahuan konsep guru dalam mengajarkan kembali konsep matematika tersebut. Sehingga analisis yang mendalam terkait dengan epistemological obstacle bisa digunakan sebagai alat untuk merekontruksi pengetahuan konsep matematika guru.

Pandangan Montessori bahwa anak harus memiliki wujud pengalaman yang bermakna untuk membedakan berbagai bentuk agar dapat membantu anak untuk mengenali dan mengingat bentuk (Ahlquist \& Gynther, 2019). Memberikan pengalaman belajar bermakna untuk anak usia dini dianggap penting bagi persiapan sekolah dan untuk keberhasilan pembelajaran masa depan mereka (Brenneman, 2011; Rasyid et al., 2021; Sancar-Tokmak, 2015). Proses pelaksanaan refleksi implementasi pembelajaran perlu di jadikan acuan supaya tujuan dapat di capai dengan maksimal.

Melalui proses didactical design research diharapkan menjadi sarana pengembangan professional. Pada proses didactical design research dikenal segitiga didaktis. Dimana segitiga didaktis tersebut adalah 
menciptakan suatu situasi didaktis (didactical situation) sehingga terjadi proses belajar dalam diri siswa (learning situation) (Suryadi, 2013a). Peran seorang guru selain perlu menguasai secara utuh konsep materi yang akan di ajarkan dan memiliki pengetahuan yang terkait dengan pengetahuan siswa serta mampu menciptakan situasi didaktis yang dapat mendorong proses belajar secara optimal. Hubungan segitiga didaktis menjadi acuan oleh guru dalam merancang siatuasi pembelajaran baik yang bersifat pedagogis mauapun didaktis. Untuk dapat melihat lebih jelas hubungan segitiga (guru, siswa dan materi pelajaran), lihat pada Gambar 1.

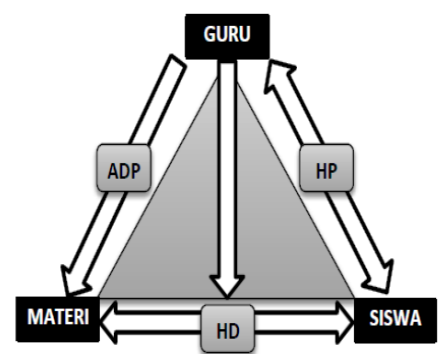

Gambar 1. Hubungan segitiga didaktis

Antisipasi didaktis pedagogis pada kajian desain didaktis merupakan pengembangan dari analisis epistemological obstacle yang dikembangkan dengan tujuan utama mengatasi learning obstacles yang dihadapi oleh siswa dan tentunya desain didaktis yang dikembangkan dapat membentuk concept image yang sesuai dengan scientific conception, berdasarkan hal tersebut paradigma interpretasi-kritis pada proses didactical design research dapat digunakan untuk mendorong daya kreatif guru Pendidikan anak usia dini, sehingga mampu memunculkan ide-ide ataupun terobosan-terobosan untuk mengembangkan desain didaktis yang lebih baik.

\section{b. Concept-Image dan Concept Definition}

Realitas fenomena yang terjadi pada sebelum, saat dan sesudah pembelajaran merupakan objek kajian didactical design research diantaranya cakupan kajian tersebut adalah learning obstacles dan concept image yang terbentuk dalam diri siswa sebagai dampak proses belajar dengan desain didaktis tertentu. Concept image suatu konsep matematika ini bukan hanya dialami oleh siswa saja tetapi juga dialami oleh guru yang mengajarkan konsep tersebut. Concept image yang dimiliki guru berdampak pada proses pemahaman dan pemaknaan konsep siswa. Pemodelan paling sederhana untuk proses kognitif siswa dibangun menggunakan concept image dan concept defenition. Bentuk-bentuk geometri yang di perkenalkan di tingkat Pendidikan anak usia dini di mulai dengan bentuk-bentuk segitiga, persegi dan persegi Panjang. Konsep-konep tersebeut merupakan dasar untuk mempelajari konsep geometri yang lebih kompleks. Sifat matematika yang hirarkinya jelas kemudian logis dan sistematis tentunya hal tersebut tidak bisa dilepaskan dari proses pembelajaran di Pendidikan anak usia dini, karena kesadaran kita bahwa matematika tidak hanya mengajarkan konsep tetapi matematika merupakan alat untuk mengembangkan kemampuan proses berpikir yang akan berdampak pada perkembangan kognitif siswa.

Temuan pada penelitian ini terkait dengan concept image dan concept definition yaitu guru Pendidikan anak usia dini yang menjadi partisipan penelitian belum sepenuhnya menyadari bahwa matematika merupakan sarana untuk meningkatkan kemampuan berpikir. Pembelajaran geometri di 
maknai sebagai proses memperkenalkan bentuk-bentuk geometri, tanpa di sadari bahwa bentuk-bentuk tersebut merupakan bentuk sederhana yang menjadi dasar bentuk yang lebih kompleks, ataupun mereka tidak menyadari bahwa bentuk-bentuk tersebut merupakan sarana berlatih berpikir logis. Berdasarkan hasil wawancara untuk mendalami pengetahuan guru terkait dengan konsep-konsep geometri, spesifik pada konsep segitiga dan persegi mereka menjelaskan bahwa segitiga merupakan suatu bentuk bangun datar yang memiliki tiga sisi begitu juga ketika menjelaskan persegi merupakan bangun datar yang memiliki empat sisi.

Penjelasan guru Pendidikan anak usia dini terkait dengan makna konsep segitiga dan persegi tersebut, memberikan informasi terkait dengan scientific conception mereka. Sajian pada proses pembelajaran yang digunakan oleh guru langsung mengarah kepada bentuk segitiga ataupun persegi. Sehingga apa yang disajikan oleh guru pada saat proses pembelajaran merupakan sebuah concept image mereka terkait dengan konsep segitiga, persegi dan persegi panjang. Jika kita melihat berdasarkan learning obstacles yang di hadapi siswa yaitu "Kesulitan memahami bagianbagian bentuk geometri" terdapat indikasi apa yang disampaikan oleh guru tidak sesuai dengan scientific conception, sehingga dapat menyebabkan persepsi yang salah mengenai suatu konsep tersebut. Jika persepsi tersebut tidak ditangani secara tepat dapat menimbulkan masalah dalam memahami materi selanjutnya, sehingga dapat menimbulkan concept image siswa yang tidak sesuai dengan scientific conception. Fenomena kesenjangan (Zone of Concept Image
Different antara siswa, guru dan scientific conception) tersebut merupakan kajian didactical design research.

Hasil penelitian menunjukkan jika antara guru dan matematikawan terdapat kesenjangan concept image, maka akan terjadi juga kesenjangan concept image antara siswa dan matematikawan yang akan berdampak pada pemahaman dan pemaknaan siswa terhadap konsep matematika lainnya (Maulida, 2018). Hasil penelitian lainnya yaitu ketika seorang guru tidak bisa mengkomunikasikan mata pelajaran secara efektif, hal itu mempengaruhi pemahaman siswa dan menyebabkan concept image siswa menyimpang dari konsepsi ilmiah (Jatisunda, Suciawati, et al., 2021). Sehingga melalui kegiatan didactical design research guru berlatih mempersiapkan matematika yang lebih sesuai dengan kebutuhan siswa untuk menghindari kesenjangan concept image. Karena proses mempersiapkan matematika yang bagi siswa dapat dijelaskan dari sudut pandang yang berbeda dan dengan kerangka teori yang berbeda (Jamilah et al., 2020). Terdapat tiga elemen ketika pertama kali mempersiapkan matematika untuk di ajarkan yaitu justification, possibility, dan implementation (Niss, 1994). Justification terkait dengan subjek yang belajar matematika, possibility merupakan kajian yang mendalam terkait dengan kondisi subjek, dan terakhir implementation merupakan kajian pelaksanaan proses pembelajaran. Ketiga elemen tersebut disebut dengan elementarization, di mana dipahami sebagai versi konstruktif dari langkah pertama dalam proses transposisi didaktis. Proses elementaryzation merupakan transformasi dari substansi matematika di tingkat universitas menjadi substansi yang lebih 
elementer dan dapat diajarkan di sekolah serta dapat dipahami siswa.

Artinya terjadi perubahan bentuk pengetahuan yang disesuaikan dengan keadaan dimana pengetahuan itu berada. Pengetahuan menjadi disesusaikan dengan institusi seperti halnya tanaman beradaptasi dengan lingku- ngannya (Achiam, 2014). Desain didaktis pembelajaran pada anak usia dini, anak diarahkan untuk memperoleh pengalaman belajar yang bermakna (Jatisunda, Hidayanti, et al., 2021). Proses adapatasi itu (Chevallard, 1989) seperti pada Gambar 2.

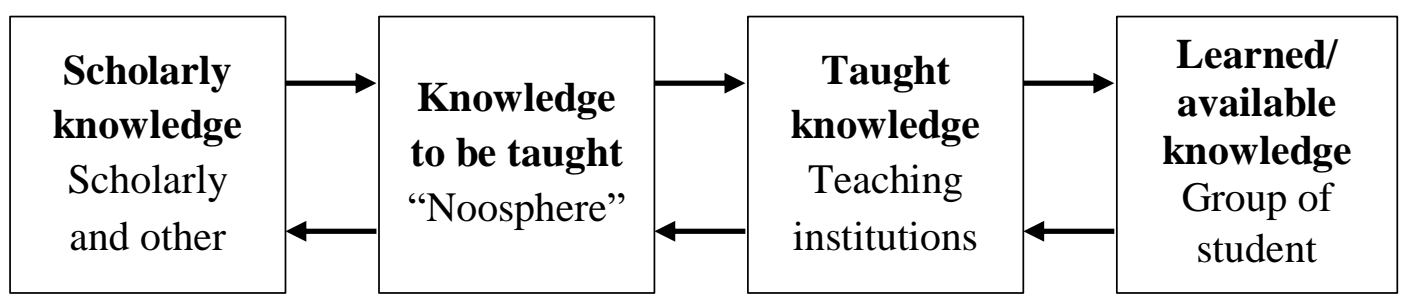

Gambar 2. Proses transposisi didaktik

Objek pengetahuan ilmiah dihasilkan, biasanya dalam konteks penelitian, kemudian disusun kembali dalam konteks sosial untuk menjadi bagian dari pengetahuan yang akan diajarkan. Transformasi selanjutnya pengetahuan menjadi konteks pengajaran, misalnya ruang kelas. Terakhir pengetahuan yang diperoleh oleh peserta didik, menjadi pengetahuan yang dipelajari. Sehingga berdasarkan hal tersebut guru dalam hal ini guru Pendidikan anak usia dini perlu menguasai pengetahuan matematika yang utuh. Spesifik pada proses pembelajaran geometri yang jadi objek pada kajian ini tentunya pengetahuan guru harus utuh di mulai dari scientific conception (scholarly Knowledge), menguasai kurikulum, menguasai materi yang akan diajarkan, dan terakhir mengetahui pengetahuan yang terbentuk di siswa sebagai akibat dari proses pembelajaran. Melalui proses transposisi didaktis diharapkan langkahlangkah scientific conception tetap terjaga, dan tentunya tujuan utama matematika sebagai alat pengembangan proses berpikir saintifik bisa tercapai. Dampak utama bagi guru adalah ketika mereka menguasai secara utuh konsepkonsep geometri akan memberikan scientific conception terhadap konsep tersebut utuh dan benar sebagai cara mengurangi kesenjangan zone of concept image different dan melalui kegiatan didactical design research guru mendapatkan pengalaman tersebut.

\section{c. Hypothetical Learning Trajectory}

Pendidikan tentunya dan pasti memiliki tujuan pembelajarannya masing-masing. Tujuan pembelajaran tersebut dapat dicapai dengan jika alur pembelajaran yang digunakan jelas dan tidak salah arah. Langkah selanjutnya yang dilakukan pada proses pengembangan professional guru Pendidikan anak usia dini adalah penyusunan hypothetical learning trajectory, yang meupakan serangkaian atau alur belajar yang akan dilalui oleh siswa untuk mencapai tujuan pembelajaran lebih bermakna. Penyusunan hypothetical learning trajectory didasarkan pada analisis yang sebelumnya sudah dilakukan yaitu analisis learning obstacles dan analisis concept image yang disajikan pada Gambar 3. 


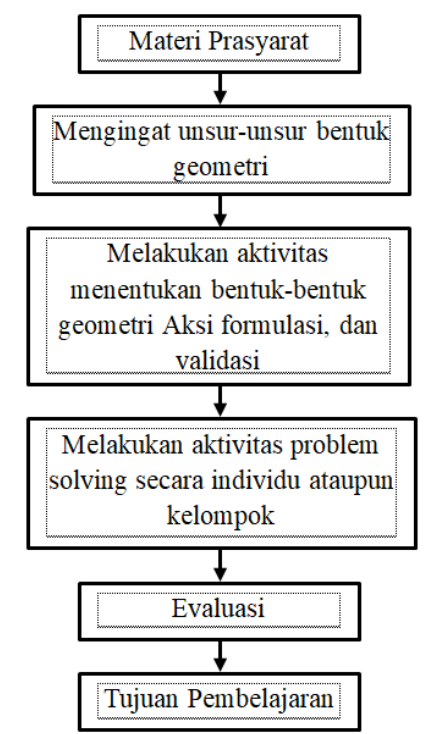

Gambar 3. Hypothetical learning trajectory

Terdapat beberapa bagian pada hypothetical Learning Trajectory diantaranya learning goal, learning activities, dan cara berpikir siswa. Penyusunan hypothetical Learning Trajectory dengan memperhatikan learning goal berarti disusun berdasarkan pertimbangan identifikasi kemampuan berpikir siswa supaya dapat mencapai tujuan pembelajaran. Selanjutnya memperhatikan learning activities dalam kajian ini aktivitas pembelajaran memperhatikan apa yang sudah di analisis yaitu learning obstacles dan concept image siswa yang merupakan bagian dari aktivitas proses refleksi pembelajaran berbasis didactical design research. Melalui aktivitas penyusunan hypothetical learning Trajectory para guru mendapatkan pengalaman sistematis dalam mencapai tujuan pembelajaran. Hypothetical learning trajectory memberikan arahan pada guru untuk berinteraksi secara langsung dengan siswa, mengamati sejauh mana pemahaman konsep siswa, mengaplikasikan berbagai jenis tugas sesuai dengan kebutuhannya, dan memunculkan permasalahan-permasalahan konstruktif yang dapat memberikan peningkatan kemampuan berpikir siswa ketika memahami konsep baru.

Hasil penelitian terkait dengan implementasi HLT ini disusun berdasarkan analisis terhadap Learning Obstacle, tahap berpikir siswa, dan analisis terhadap kurikulum dengan tetap berpijak pada konsep materi yang harus dipahami siswa (Fuadiah, 2017). HLT yang terencana dengan baik memungkinkan guru untuk melakukan tindakan pembelajaran sesuai kebutuhan siswa (Fuadiah, 2019). HLT merupakan alur dugaan pikiran siswa dalam mempelajari suatu topik, dapat memperlihatkan hubungan yang saling mempengaruhi antara kegiatan dan proses pembelajaran (Rezky \& Jais, 2020). Berbagai hasil penelitian menggunakan HLT untuk meningkatkan kemampuan siswa pemahaman konsep (Putra \& Saputra, 2018).

Penyusunan HLT merupakan bagian akhir dari proses refleksi pembelajaran yang dilaksanakan oleh guru. Berdasarkan analisis learning obstacles dan juga analisis kesenjangan concept image dangan concept definition HLT di susun dengan menyesuaikan kebutuhan siswa. Semua kegiatan yang dilaksanakan menjadi suatu proses yang harus dilakukan oleh guru untuk meningkatkan kualitas pembelajaran.

\section{KESIMPULAN DAN SARAN}

Secara umum hasil analisis temuan data penelitian dan pembahasannya adalah analisis terkait dengan isu-isu yang menjadi point penting pada setiap pertemuan proses refleksi diataranya adalah learning obstacles, concept image dan hypothetical learning trajectory. 
Temuan learning obstacles yang di hadapi oleh siswa berdasarkan hasil analisis para guru mengarah pada epistemological obstacle yaitu kesulitan mengingat dan mengenal bentuk geometri dan kesulitan memahami bagian-bagian bentuk geometri. Kemudian concept image Guru memaknai konsep segitiga dan konsep persegi sebagai bentuk bangun datar yang memiliki tiga sisi begitu juga ketika menjelaskan persegi merupakan bangun datar yang memiliki empat sisi. Jawaban tersebut merupakan gambaran concept image dan concept definition yang menjadi dasar pengetahuan guru mengajarkan kepada anak. Terdapat indikasi guru mengajarkan geometri tidak sesuai dengan konsepnya ini terlihat dari learning obstacles yang didapatkan. Aktivitas selanjutnya membuat hypothetical learning trajectory dengan memperhatikan yaitu learning obstacles dan concept image. Melalui aktivitas penyusunan hypothetical learning Trajectory para guru mendapatkan pengalaman sistematis dalam mencapai tujuan pembelajaran.

Keterbatasan dalam penelitian ini adalah analisis setiap langkah pada proses didactical design research belum tergambarkan secara utuh hanya tiga kajian yang didalami, sehingga untuk penelitian selanjutnya setiap langkah dapat tergambarkan secara jelas untuk melihat dampak yang lebih nyata dari proses pengembangan professional yang telah dilaksanakan, sehingga untuk penelitian selanjutnya proses refleksi pembelajaran yang sudah dilakukan bisa digambarkan secara jelas.

\section{DAFTAR PUSTAKA}

Achiam, M. (2014). Didactic Transposition: From theoretical notion to research programme. ESERA Summer School,
Kapadokya, Turkey, August 24, 29, 2014.

https://doi.org/doi:10.1016/j.sbspro. 2010.12.052

Ahlquist, E.-M. T., \& Gynther, P. (2019). Variation theory and Montessori education. Journal of Montessori Research I\& Education, 2(1). https://doi.org/10.16993/jmre.12

Apriyanti, H. (2017). Pemahaman Guru Pendidikan Anak Usia Dini Terhadap Perencanaan Pembelajaran Tematik. Jurnal Obsesi: Jurnal Pendidikan Anak Usia Dini, 1(2), 111-117. https://doi.org/10.31004/obsesi.v1i2 .22

Barut, M. E. O. B., Wijaya, A., \& Retnawati, H. (2020). Analisis hubungan antara pedagogical content knowledge guru matematika dan prestasi belajar siswa sekolah menengah pertama. Pythagoras: Jurnal Pendidikan Matematika, 15(2), 178-190. https://doi.org/10.21831/pg.v15i2.3 5375

Beynon, K. A., \& Zollman, A. (2015). Lacking a formal concept of limit: Advanced non-mathematics students' personal concept definitions. Investigations in Mathematics Learning, 8(1), 4762.

https://doi.org/10.1080/24727466.2 015.11790347

Bintoro, H. S., \& Sumaji, S. (2021). Proses Berpikir Spasial Ditinjau dari Kecerdasan Intrapersonal Mahasiswa Pendidikan Matematika. AKSIOMA: Jurnal Program Studi Pendidikan Matematika, 10(2), 1074-1087. https://doi.org/10.24127/ajpm.v10i2 .3641

Brousseau, G. (1989). Les obstacles épistémologiques et la didactique des mathématiques. 
DOI: https://doi.org/10.24127/ajpm.v10i4.4005

Chevallard, Y. (1989). On didactic transposition theory: Some introductory notes. Proceedings of The International Symposium on Selected Domains of Research and Development in Mathematics Education. Bratislava.

Clements, D. H., \& Sarama, J. (2011). Early childhood teacher education: The case of geometry. Journal of Mathematics Teacher Education, 14(2), 133-148. https://doi.org/10.1007/s10857011-9173-0

Creswell, J. W. (2012). Educational Research: Planning, Conducting and evaluating Quantitative and Qualitative Research (4th ed). Pearson education, Inc.

de Weerd, L., \& Verhoef, N. (2015). The link between the cognitive structure and modelling to improve mathematics education. CERME 9Ninth Congress of the European Society for Research in Mathematics Education, 930-936.

Dreyfus, T. (2014). Solid Findings: Concept Images in Students' Mathematical Reasoning. Newsletter of the European Mathematical Society, 93, 50-52.

Engelke Infante, N., Murphy, K., Glenn, C., \& Sealey, V. (2018). How concept images affect students' interpretations of Newton's method. International Journal of Mathematical Education in Science and Technology, 49(5), 643-659. https://doi.org/10.1080/0020739X.2 017.1410737

Fauzi, I. K. A. (2017). Potensi gugus PAUD untuk pembinaan paska pelatihan pendidik anak usia dini dengan menggunakan lesson study. JPPM (Jurnal Pendidikan Dan Pemberdayaan Masyarakat), 4(1), 37-50.

Fuadiah, N. F. (2017). Hypothetical Learning Trajectory pada
Pembelajaran Bilangan Negatif Berdasarkan Teori Situasi Didaktis di Sekolah Menengah. Mosharafa: Jurnal Pendidikan Matematika, 6(1), 13-24. https://doi.org/10.31980/mosharafa. v6i1.290

Fuadiah, N. F. (2019). Hypothetical Learning Trajectory Dan Peranannya Dalam Perencanaan Pembelajaran Matematika. Jurnal Dosen Universitas PGRI Palembang.

Habineza, F. (2013). A case study of analyzing student teachers' concept images of the definite integral. Rwandan Journal of Education, 1(2), 38-54. https://www.ajol.info/index.php/rje/ article/view/111569/101346

Hachey, A. C. (2013). The early childhood mathematics education revolution. Early Education \& Development, 24(4), 419-430. https://doi.org/10.1080/10409289.2 012.756223

Harris, D. N., \& Sass, T. R. (2011). Teacher training, teacher quality and student achievement. Journal of Public Economics, 95(7-8), 798812.

https://doi.org/10.1016/j.jpubeco.20 10.11.009

Insani, M. I., \& Kadarisma, G. (2020). Analisis Epistemological Obstacle Siswa SMA pada Materi Trigonometri. JPMI (Jurnal Pembelajaran Matematika Inovatif), 3(5), 547-558. https://doi.org/10.22460/jpmi.v3i5. 547-558

Jamilah, J., Suryadi, D., \& Priatna, N. (2020). Didactic transposition from scholarly knowledge of mathematics to school mathematics on sets theory. Journal of Physics: Conference Series, 1521(3), 32093. https://doi.org/10.1088/17426596/1521/3/032093 
Jatisunda, M. G., Hidayanti, M., Nahdi, D. S., Cahyaningsih, U., Suciawati, V., \& others. (2021). Mathematical knowledge for early childhood teaching: A deep insight on how pre-service teachers prepare mathematical activities. Journal of Physics: Conference Series, 1778(1), 12017. https://doi.org/:10.1088/17426596/1778/1/012017

Jatisunda, M. G., Suciawati, V., \& Nahdi, D. S. (2021). Pythagorean Theorem Concept Image in Junior High School: An Analysis in The OnlineBased Learning. Jurnal Didaktik Matematika, 8(2), 235-249. https://doi.org/10.24815/jdm.v8i2.2 1902

Johnson, H. L., Blume, G. W., Shimizu, J. K., Graysay, D., \& Konnova, S. (2014). A teacher's conception of definition and use of examples when doing and teaching mathematics. Mathematical Thinking and Learning, 16(4), 285311.

https://doi.org/10.1080/10986065.2 014.953018

Jung, M., \& Conderman, G. (2017). Early geometry instruction for young children. Kappa Delta Pi Record, 53(3), 126-130. https://doi.org/10.1080/00228958.2 017.1334478

Khali, M., \& Khalil, U. (2019). Geogebra as a Scaffolding Tool for Exploring Analytic Geometry Structure and Developing Mathematical Thinking of Diverse Achievers. International Electronic Journal of Mathematics Education, 14(2), 427-434. https://doi.org/10.29333/iejme/5746 Lasauskien, J., Rauduvait, A., \& Barkauskait, M. (2015). Development of general competencies within the context of teacher training. Procedia-Social and Behavioral Sciences, 191, 777-
782.

https://doi.org/10.1016/j.sbspro.201 5.04.525

Lestarai, U. (2019). Analisis Learning Obstacle Pada Pembelajaran Nilai Tempat Siswa Kelas II SD [Learning Obstacle Analysis on Place Value Learning in Students Class II Elementary School]. PEDAGOGIA: Jurnal Pendidikan, 8(1), 61-68. https://doi.org/10.21070/pedagogia. v8i1.1854

Lisa, L. (2017). Prinsip dan Konsep Permainan Matematika Bagi Anak Usia Dini. Bunayya: Jurnal Pendidikan Anak, 3(1), 93-107. https://jurnal.arraniry.ac.id/index.php/bunayya/arti cle/viewFile/2047/1518

Liu, L., \& Zhang, Y. (2014). Enhancing Teachers' Professional Development through Reflective Teaching. Theory \& Practice in Language Studies, 4(11).

Lo, W. Y. (2021). Pre-Service Teachers' Prior Learning Experiences of Mathematics and the Influences on Their Beliefs about Mathematics Teaching. International Journal of Instruction, 14(1), 795-812. https://doi.org/10.29333/iji.2021.14 $148 \mathrm{a}$

Maiza, Z., \& Nurhafizah, N. (2019). Pengembangan Keprofesian Berkelanjutan dalam Meningkatkan Profesionalisme Guru Pendidikan Anak Usia Dini. Jurnal Obsesi: Jurnal Pendidikan Anak Usia Dini, 3(2), 356-465. https://doi.org/10.31004/obsesi.v3i2 .196

Maizora, S., \& Rosjanuardi, R. (2020). Konsepsi siswa kelas tiga sekolah dasar tentang bilangan bulat. Pythagoras: Jurnal Pendidikan Matematika, 15(2). https://doi.org/10.21831/pg.v15i2.3 7645 
DOI: https://doi.org/10.24127/ajpm.v10i4.4005

Maulida, L. (2018). Kajian Concept Image Pada Materi Sistem Pertidaksamaan Linear Dua Variabel.

Moser, A., \& Korstjens, I. (2018). Series: Practical guidance to qualitative research. Part 3: Sampling, data collection and analysis. European Journal of General Practice, 24(1), $9-18$.

https://doi.org/10.1080/13814788.2 017.1375091

$\mathrm{Ng}$, D. (2011). Indonesian primary teachers' mathematical knowledge for teaching geometry: implications for educational policy and teacher preparation programs. Asia-Pacific Journal of Teacher Education, 39(2), 151-164. https://doi.org/10.1080/1359866x.2 011.560648

Niss, M. (1994). Mathematics in society. Didactics of Mathematics as a Scientific Discipline, 13, 367-378.

Noviyanti, M. (2019). Professional Development Program Untuk Membangun Mathematical Knowledge for Teaching Guru Pendidikan Anak Usia Dini.

Nuraeni, Y., Sukirwan, S., \& Khaerunnisa, E. (2021). Analisis Learning Obstacle Dalam Materi Hubungan Antar Sudut Siswa Kelas VII. JPPM (Jurnal Penelitian Dan Pembelajaran Matematika), 14(1), 73-87.

https://doi.org/10.30870/jppm.v14i 1.10478

Putra, Y. Y., \& Saputra, A. (2018). The applying of hypothetical learning trajectory (HLT) on comparison material using nisab zakat theory toward the student's learning outcomes. Al-Jabar: Jurnal Pendidikan Matematika, 9(2), 135146.

https://doi.org/10.24042/ajpm.v9i2. 2950
Rezky, R., \& Jais, E. (2020). Hyphotetical Learning Trajectory: Pemecahan Masalah Materi Sistem Persamaan Linear Dua Variabel. Mandalika Mathematics and Education Journal, 2(2), 92-101. https://doi.org/10.29303/mandalika. v2i1.1780

Rismayantini, R., Kadarisma, G., \& Rohaeti, E. E. (2021). Analisis Epistemological Obstacle pada Materi Perbandingan Siswa SMP Kelas VIII. JPMI (Jurnal Pembelajaran Matematika Inovatif), 4(1), 81-90. https://doi.org/10.22460/jpmi.v4i1. 81-90

Rohimah, S. M. (2017). Analisis Learning Obstacles Pada Materi Persamaan Dan Pertidaksamaan Linear Satu Variabel. JPPM (Jurnal Penelitian Dan Pembelajaran Matematika), 10(1). https://doi.org/10.30870/jppm.v10i 1.1293

Rohmah, S. K. (2019). Analisis Learning Obstacles Siswa pada Materi Pecahan Kelas IV Sekolah Dasar. Al-Aulad: Journal of Islamic Primary Education, 2(1). https://doi.org/10.15575/alaulad.v2i1.4428

Rudi, R., Suryadi, D., \& Rosjanuardi, R. (2020). Teachers' Perception as a Crucial Component in the Design of Didactical Design ResearchBased Teacher Professional Learning Community in Indonesia. European Online Journal of Natural and Social Sciences, 9(3), pp-642.

Sloan, A., \& Bowe, B. (2014). Phenomenology and hermeneutic phenomenology: The philosophy, the methodologies, and using hermeneutic phenomenology to investigate lecturers' experiences of curriculum design. Quality \& Quantity, 48(3), 1291-1303. 
DOI: https://doi.org/10.24127/ajpm.v10i4.4005

https://doi.org/10.1007/s11135013-9835-3

Smith, J. A., Flowers, P., \& Larkin, M. (2021). Interpretative phenomenological analysis: Theory, method and research. sage. Suryadi, D. (2010). Menciptakan proses belajar aktif: Kajian dari sudut pandang teori belajar dan teori didaktik. Bandung: Tidak Diterbitkan.

Suryadi, D. (2013a). Didactical design research (DDR) to improve the teaching of mathematics. Far East Journal of Mathematical Education, 10(1), 91-107.

Suryadi, D. (2015). Refleksi Kritis Tradisi Pendidikan Matematika dan Sebuah Gagasan Alternatif. In Pendidikan Disiplin Ilmu Abad 21: Sebuah Kajian Prospektif.

Suryadi, D. (2018). Ontologi dan epistemologi dalam penelitian desain didaktis (DDR). Bandung: Departemen Pendidikan Matematika Universitas Pendidikan Indonesia.

Suryadi, D. (2013b). Didactical design research (DDR) dalam pengembangan pembelajaran matematika. Prosiding Seminar Nasional Matematika Dan Pendidikan Matematika, 1, 3-12.

Susianna, N., \& Suhandi, F. (2014). Program lesson study untuk meningkatkan kompetensi pedagogi dan profesional guru PAUD di sekolah XYZ Jakarta. Jurnal Pendidikan Dan Pembelajaran (JPP), 21(1), 41-47.

Tsamir, P., Tirosh, D., Levenson, E., Barkai, R., \& Tabach, M. (2015). Early-years teachers' concept images and concept definitions: triangles, circles, and cylinders. ZDM, 47(3), 497-509. https://doi.org/10.1007/s11858-

014-0641-8 van Manen, M. (2016). Researching lived experience: Human science for an action sensitive pedagogy. Routledge.

Verissimo, S., Lopes, V. G., Garcia, L. M. C., \& González, R. L. (2017). Evaluation of changes in cognitive structures after the learning process in mathematics. International Journal of Innovation in Science and Mathematics Education, 25(2). https://openjournals.library.sydney. edu.au/index.php/CAL/article/view/ 11295

Waspodo, M. (2012). Pengembangan Profesional Berkelanjutan bagi Guru PAUD. Jurnal Ilmiah Visi, 7(1), 77-81. 